\title{
THE EXISTENCE OF AMMONIA IN BLOOD IN VIVO WITH OBSERVATIONS ON THE SIGNIFICANCE OF THE $\mathrm{NH}_{4}{ }^{+}-\mathrm{NH}_{3}$ SYSTEM *
}

\author{
By PHILIP A. BROMBERG, $\dagger$ EUGENE D. ROBIN $\ddagger$ AND CLAUDE E. FORKNER, JR.§ \\ (From the Department of Medicine, Harvard Medical School and the Medical Clinics of the \\ Peter Bent Brigham Hospital, Boston, Mass.)
}

(Submitted for publication July 31, 1959; accepted October 6, 1959)

The development of refined methods for determination of blood ammonia in the past 50 years has resulted in a gradual lowering of the reported concentrations in the peripheral venous blood of normal man (1). After extensive work with a microdiffusion technique, Conway and Cooke concluded that the normal in vivo peripheral venous level of the blood ammonia nitrogen in man was operationally zero, but that rapid liberation of ammonia from certain precursors occurred after shedding to produce in vitro values of about $35 \mu$ moles ammonia-nitrogen $\left(\mathrm{NH}_{3}-\mathrm{N}\right)$ per L blood (2). Identical conclusions were reached by Koprowski and Uninski in their work on dog blood (3), using Conway's method. The results of more recent investigations using different techniques (4-7) have indicated that peripheral venous blood does contain significant amounts of ammonia in vivo. This conflict has not been resolved despite frequent use of the Conway method in many investigations of human ammonia metabolism in the past decade.

The present experiments were stimulated by the observation that dogs receiving intravenous infusions of ammonium salts excreted measurable amounts of $\mathrm{NH}_{3}$ gas in expired air (8). This ammonia was presumably derived from the dissolved $\mathrm{NH}_{3}$ gas which must exist in equilibrium

\footnotetext{
* This investigation was supported in part by a research grant (H-2243) from the National Heart Institute, Bethesda, Md., and in part by a grant from the Massachusetts Heart Association. Some of these data have been presented at a meeting of the American Society for Clinical Investigation, May 3, 1959.

$\dagger$ Fellow of the National Foundation.

$\ddagger$ Present address : Department of Medicine, University of Pittsburgh Medical School, Pittsburgh, $\mathrm{Pa}$. Requests for reprints should be sent to this address.

$\S$ Public Health Service Research Fellow of the $\mathrm{Na}$ tional Heart Institute.
}

with $\mathrm{NH}_{4}{ }^{+}$ion in plasma and which entered alveolar air during the passage of blood through the pulmonary capillaries.

It was thought that some of the physicochemical properties of the $\mathrm{NH}_{4}{ }^{+}-\mathrm{NH}_{3}$ system could be investigated in vivo in animals receiving substantial amounts of ammonium salts intravenously and could be compared with the properties of the same system in animals not receiving ammonium salts. Consistent similarity in behavior of the $\mathrm{NH}_{4}{ }^{+}-\mathrm{NH}_{3}$ system in both groups of animals would constitute strong evidence that the measured endogenous arterial blood ammonia concentrations actually existed in vivo and did not represent post-shedding decomposition artifact.

Three properties of the $\mathrm{NH}_{4}{ }^{+}-\mathrm{NH}_{3}$ system have been investigated :

1. The partial pressure of ammonia gas in the alveolar air $\left(\mathrm{PA}_{\mathrm{NH}_{3}}\right)$ as a function of arterial $\mathrm{pH}$ and arterial total ammonium level. From these data, a $\mathrm{pK}_{\mathrm{a}}^{\prime}$ for the equilibrium $\mathrm{NH}_{4}{ }^{+} \rightleftharpoons$ $\mathrm{NH}_{3}+\mathrm{H}^{+}$could be calculated for both groups;

2. The relationship between cerebrospinal fluid and arterial total ammonium concentrations;

3. The behavior of the blood ammonium system when changes in blood $\mathrm{pH}$ are induced by the intravenous infusion of $\mathrm{HCl}$ or of $\mathrm{Na}$ $\mathrm{HCO}_{3}$.

Certain additional points have been investigated :

1. The stability of ammonium concentrations in trichloracetic acid filtrates of blood;

2. The relationship between plasma and erythrocyte total ammonium concentrations.

In this paper, all ammoniacal nitrogen concentrations will be expressed in micromoles per liter. "Total ammonium" refers to both the $\mathrm{NH}_{4}{ }^{+}$and $\mathrm{NH}_{3}$ fractions. Ammonia gas refers only to $\mathrm{NH}_{3}$. 


\section{METHODS}

\section{General}

Mongrel dogs weighing from 10 to $15 \mathrm{~kg}$ were used for all except a few human experiments. The dogs were anesthetized with intravenous sodium pentobarbital (30 $\mathrm{mg}$ per $\mathrm{kg}$ ). Additional sodium pentobarbital as required was given parenterally. Intravenous infusions were given through polyethylene catheters in the jugular and/or femoral veins. Arterial blood was obtained through a polyethylene catheter in a femoral artery. Cerebrospinal fluid was obtained by direct cisternal puncture.

All body fluids analyzed for total $\mathrm{NH}_{3}-\mathrm{N}$ were mixed with an approximately equal volume of ice-cold 20 per cent trichloracetic acid and the resultant protein-free filtrates analyzed in triplicate using the ninhydrin method of Nathan and Rodkey (7). The optical densities were read at $560 \mathrm{~m} \mu$ against a water blank in a Coleman Model 6-A Junior Spectrophotometer. Preliminary experiments confirmed the conclusions of Nathan and Rodkey on the recovery of ammonia added to blood and on the linearity of intensity of ninhydrin color development with solutions containing at least up to $300 \mu$ moles $\mathrm{NH}_{3}-\mathrm{N}$ per $\mathrm{L}$. Calculations were done as described by Nathan and Rodkey. In the early experiments, trichloracetic acid filtrates were analyzed on the day of preparation. After it was demonstrated that the $\mathrm{NH}_{3}-\mathrm{N}$ content was stable when kept frozen at $-10^{\circ} \mathrm{C}$ (see below), filtrates were frozen up to several days prior to analysis.

In experiments involving analysis of plasma and/or packed cells, the blood was drawn anaerobically into an oiled heparinized syringe. Ten $\mathrm{ml}$ was extruded into a test tube under mineral oil by means of a no. 14 polyethylene catheter and centrifuged 10 minutes at $2,500 \mathrm{rpm}$. About $3 \mathrm{ml}$ plasma was then aspirated aerobically and immediately mixed with $3.0 \mathrm{ml}$ ice-cold 20 per cent trichloracetic acid. In packed cell analyses, $3 \mathrm{ml}$ of cells was mixed with $5.0 \mathrm{ml} 20$ per cent trichloracetic acid to prepare the filtrates. By anaerobic handling it was hoped to maintain $\mathrm{CO}_{2}$ tension, thus inhibiting in vitro formation of ammonia after shedding, ${ }^{1}$ and also to prevent possible $\mathrm{NH}_{3}$ gas loss from the more alkaline blood samples.

Cerebrospinal fluid analyses were usually performed in triplicate on the filtrates obtained by the addition of approximately $2 \mathrm{ml}$ of cerebrospinal fluid to $2.0 \mathrm{ml} 20$ per cent trichloracetic acid.

Blood $\mathrm{pH}$ was measured anaerobically by means of a Beckman Model $\mathrm{G}$ pH meter. Readings were made at room temperautre and converted to $37^{\circ} \mathrm{C}$ by the Rosenthal correction factor (11). Samples were collected in oiled heparinized syringes. Total $\mathrm{CO}_{2}$ content of blood was determined by the technique of Van Slyke and Neill (12). Plasma $\mathrm{CO}_{2}$ content was calculated from whole blood $\mathrm{CO}_{2}$, hematocrit, and $\mathrm{pH}$ by means of the

1 Several investigators have reported the marked inhibitory effect of the maintenance of $\mathrm{CO}_{2}$ tension on the release of ammonia after shedding $(2,9,10)$. correction factors of Van Slyke and Sendroy (13). Arterial plasma $\mathrm{CO}_{2}$ tensions $\left(\mathrm{Paco}_{2}\right)$ were calculated by means of the Henderson-Hasselbalch equation using a $\mathrm{pK}_{\mathrm{a}}^{\prime}$ of 6.10 (14), and a solubility factor of 0.0301 mmole per $\mathrm{L}$ per $\mathrm{mm} \mathrm{Hg}$ for $\mathrm{CO}_{2}$ in plasma (15).

Expired air for ammonia determination was bubbled through a trap containing 5 or $10 \mathrm{ml}$ of $0.1 \mathrm{~N} \mathrm{HCl}$ as described by Robin and associates (8). The $\mathrm{HCl}$ solution was then analyzed in triplicate using the procedure of Nathan and Rodkey (7).

Expired air was collected in a Douglas bag or in a meteorological balloon connected in series to the $\mathrm{HCl}$ trap outflow. Expired volumes $\left(\mathrm{V}_{\mathrm{E}}\right)$ were measured in a Tissot spirometer. $\mathrm{CO}_{2}$ tension in the expired air $\left(\mathrm{P}_{\mathrm{E}} \mathrm{CO}_{2}\right)$ was measured by a Liston Becker infrared $\mathrm{CO}_{2}$ analyzer.

\section{II. $p K_{\mathrm{a}}^{\prime}$ determinations}

A. Infused dogs ( 9 animals). Following anesthesia and insertion of catheters and endotracheal tube, a priming dose of $0.2 \mathrm{M}$ ammonium acetate was infused at about $1 \mathrm{mEq}$ per minute for 20 to 30 minutes. The infusion rate was then reduced to 0.3 to $0.5 \mathrm{mEq}$ per minute and maintained at that level with a Bowman constant infusion pump throughout the experiment. After 15 minutes of equilibration, a 20 minute air sample collection for $\mathrm{NH}_{3}$ analysis was bubbled through a $\mathrm{HCl}$ trap. Midway through the $\mathrm{NH}_{3}$ air collection period, a 3 to 5 minute expired air sample was obtained for measurement of $\mathrm{V}_{\mathrm{E}}$ and $\mathrm{P}_{\mathrm{E}} \mathrm{CO}_{2}$. A simultaneous arterial blood was drawn for $\mathrm{Paco}$, and $\mathrm{pH}$ while a $3 \mathrm{ml}$ sample was immediately mixed with $3.0 \mathrm{ml}$ ice-cold 20 per cent trichloracetic acid for total ammonium analysis. These data permitted calculation of alveolar ventilation $\left(V_{A}\right)$ by means of the Bohr (16) relation:

$$
V_{\mathrm{A}}=V_{\mathrm{E}} \frac{\mathrm{P}_{\mathrm{E}} \mathrm{CO}}{\mathrm{PaCO}_{2}}
$$

$\mathrm{HCl}(0.5 \mathrm{~N})$ was then infused into 4 animals. A priming dose of about $75 \mathrm{mEq}$ was given at approximately $2.5 \mathrm{mEq}$ per minute. Then a slow infusion of $0.5 \mathrm{mEq}$ per minute was maintained for the remainder of the experiment. After a 15 minute equilibration period, another 20 minute air collection for $\mathrm{NH}_{3}$ analysis was obtained and $\mathrm{V}_{\mathrm{k}}, \mathrm{P}_{\mathrm{k}} \mathrm{CO}_{2}$, arterial $\mathrm{pH}$, and whole blood arterial total ammonium concentration were measured.

In 3 of the other animals, $0.9 \mathrm{~N} \mathrm{NaHCO}_{3}$ was infused using 150 to $200 \mathrm{mEq}$ as a priming dose, and 50 $\mathrm{mEq}$ at $1 \mathrm{mEq}$ per minute as a maintenance infusion. Similar measurements were obtained.

For the reaction $\mathrm{NH}_{4}^{+} \rightleftharpoons \mathrm{NH}_{3}+\mathrm{H}^{+}, \mathrm{pK}_{\mathrm{a}}^{\prime}$ was then calculated for 16 sets of data covering a $\mathrm{pH}$ range of 6.75 to 7.61. (See Calculation below:)

$B$. Uninfused dogs (10 animals). Following anesthesia and insertion of the endotracheal tube, expired air was bubbled through a 5 or $10 \mathrm{ml} \mathrm{HCl}$ trap for approximately 4 hours in order to insure analyzable concentrations of ammonia. In all experiments the entire $V_{E}$ was collected in a meteorological balloon. However, 
only a single arterial blood sample was obtained for total ammonium analysis and for $\mathrm{pH}, \mathrm{CO}_{2}$ content, and hematocrit. Since $\mathrm{pH}$ and $\mathrm{Paco}_{2}$ undoubtedly varied to some degree during the prolonged course of these experiments, the derived value of $\mathrm{V}_{\Delta}$ is only an approximation.

No body temperature determinations were done on either group of animals. Data on two human subjects were also obtained by means of endotracheal tubes during operations.

C. Calculations. From the data obtained, the alveolar tension of $\mathrm{NH}_{8}$ gas $\left(\mathrm{P}_{\mathrm{ANH}_{3}}\right)$, in millimeters of $\mathrm{Hg}$, may be calculated as indicated by Robin and associates (8). Using an $\alpha$ (Bunsen solubility coefficient) of $0.96 \mathrm{~L} \mathrm{NH}_{3}$ per $\mathrm{L}$ plasma per $\mathrm{mm} \mathrm{Hg}$ (17), the concentration of dissolved $\mathrm{NH}_{8}$ gas in $\mathrm{L}$ per $\mathrm{L}$ plasma may be calculated assuming that there is complete $\mathrm{NH}_{8}$ equilibrium between pulmonary capillary blood and alveolar air so that $\mathrm{Pa}_{\mathrm{NH}_{3}}=\mathrm{P}_{\mathrm{ANH}_{3}}$. (This is a very likely assumption in view of the great diffusiveness of $\mathrm{NH}_{3}$ gas.) Conversion from liters of $\mathrm{NH}_{3}$ gas to moles may be made using the factor of $22.1 \mathrm{~L}$ (STPD) per mole $\mathrm{NH}_{3}$ gas. Thus, $\left[\mathrm{NH}_{3}\right]$ in moles per liter of blood

$$
=\frac{\mathrm{P}_{\mathrm{ANH}_{3}} \times \alpha \mathrm{NH}_{3}}{22.1} \text {. }
$$

The total concentration of $\mathrm{NH}_{3}-\mathrm{N}$ in moles per liter of whole blood is easily derived from the concentration of $\mathrm{NH}_{3}-\mathrm{N}$ in milligrams per milliliter by dividing by 14 (atomic weight of $\mathrm{N}$ ).

In the equilibrium:

$$
\begin{aligned}
& \mathrm{NH}_{4}{ }^{+} \rightleftharpoons \mathrm{H}^{+}+\mathrm{NH}_{3} \\
& \mathrm{~K}_{\mathrm{a}}=\frac{\left[\mathrm{H}^{+}\right]\left[\mathrm{NH}_{3}\right]}{\left[\mathrm{NH}_{4}^{+}\right]} \\
& \mathrm{pK}_{\mathrm{a}}^{\prime}=\mathrm{pH}+\log \frac{\left[\mathrm{NH}_{4}{ }^{+}\right]}{\left[\mathrm{NH}_{3}\right]} \\
& =\mathrm{pH}+\log \frac{[\text { total ammonium }]-\left[\mathrm{NH}_{3}\right]}{\left[\mathrm{NH}_{3}\right]} \\
& =\mathrm{pH}+\log \left(\frac{[\text { total ammonium }]}{\left[\mathrm{NH}_{3}\right]}-1\right) .
\end{aligned}
$$

Since $\frac{\text { [total ammonium] }}{\left[\mathrm{NH}_{8}\right]}$ varies from about 30 to 250 in the $\mathrm{pH}$ range experimentally attained, the final term in the logarithm has been disregarded as being insignificant, giving the following expression for calculation of $\mathrm{pK}^{\prime}$.

$$
\mathrm{pK}_{\mathrm{a}}^{\prime}=\mathrm{pH}+\log \frac{[\text { total ammonium }]}{\left[\mathrm{NH}_{3}\right]} .
$$

Several sources of error in the determination of $\mathrm{pK}_{\mathrm{a}}^{\prime}$ must be mentioned. These errors assume greater proportions in the data obtained from noninfused animals.

1. $V_{\Delta}$ depends on $V_{E}$ (which can be measured rather exactly), and on $\mathrm{P}_{\mathrm{E}} \mathrm{CO}_{2}$ and $\mathrm{Pacos}_{2}$. These latter values undoubtedly vary to some extent throughout the experimental period so that the "average" $\mathrm{P}_{\mathrm{B}} \mathrm{CO}_{2}$ and the single point value of $\mathrm{Paco}_{2}$ do not enable an exact calculation of $\mathrm{V}_{\mathbf{A}}$.
2. Temperature was not measured in these animals. Body temperature may fall below normal in an anesthetized animal or the animal may be febrile for some other cause. Some variation of $\alpha \mathrm{NH}_{3}$ and of $\mathrm{pK}_{\mathrm{a}}^{\prime}$ with temperature has been shown to exist (17).

3. The possibility of variation of blood $\mathrm{pH}$ and of blood total ammonium concentrations, particularly during long air collections, was disregarded. This may have affected the calculations to a substantial degree.

4. Whole blood total ammonium concentrations were measured rather than plasma concentrations (which would be somewhat lower).

5. A given error is proportionately greater when measuring small total ammonium concentrations in uninfused animals.

\section{Spinal fluid arterial blood ratios of total ammonium concentration}

A. Uninfused dogs ( 7 animals). A needle with stylet was inserted atraumatically into the cisternal space and simultaneous samples of arterial blood and of cerebrospinal fluid were withdrawn. In 3 animals, 2 samples each of cerebrospinal fluid and blood were obtained. In 1 animal, 3 samples each of cerebrospinal fluid and blood were obtained. In 3 animals, single samples of cerebrospinal fluid and blood were obtained. Cerebrospinal fluid and blood trichloracetic acid filtrates were prepared and analyzed in triplicate as described previously.

$B$. Infused dogs (6 animals). Two dogs were given a constant infusion of $0.2 \mathrm{M} \mathrm{NH}_{4}$ acetate at $0.36 \mathrm{mEq}$ per minute after a priming dose of $1 \mathrm{mEq}$ ammonium acetate per minute for 15 minutes. After a steady state was established, arterial blood and cerebrospinal fluid samples were taken approximately at hourly intervals for a 6.5 hour period in one dog and a 5 hour period in another dog. Eleven simultaneous pairs of values were obtained in this way. Six other pairs of values were obtained in other experiments in which cerebrospinal fluid was withdrawn during steady state conditions.

C. Humans. Three other paired values of arterial blood and cerebrospinal fluid were obtained in human subjects with severe liver disease.

\section{Plasma-erythrocyte total ammonium ratios}

In 4 dogs receiving a constant infusion of $0.2 \mathrm{M}$ ammonium acetate, separation of erythrocytes from plasma and analysis for total ammonium concentration were carried out as described above. Arterial whole blood total ammonium and plasma $\mathrm{pH}$ were determined simultaneously.

\section{Filtrate stability}

Fifteen $\mathrm{ml}$ of venous blood was obtained from a dog receiving a constant infusion of ammonium acetate and was mixed with $15 \mathrm{ml}$ ice-cold 20 per cent trichloracetic acid. The filtrate was divided into 7 aliquots which were frozen at $-10^{\circ} \mathrm{C}$. One aliquot was analyzed at the time of obtaining the blood; the remainder was analyzed at intervals over an 8 week period. A similar procedure was 
followed with arterial blood from a dog receiving no ammonium salt infusion. Five aliquots at appropriate intervals were analyzed during a 24 day period.

\section{VI. $\mathrm{NH}_{4}^{+}-\mathrm{NH}_{3}$ system as an indicator of intracellular- extracellular acid-base relations}

The technique of these experiments has been described in detail by Robin, Bromberg and Forkner (18). Shifts in total ammonium concentration of arterial plasma in dogs receiving constant infusions of ammonium acetate were induced by infusion of $\mathrm{HCl}$ and $\mathrm{NaHCO}_{3}$ in appropriate quantities. The theory underlying such shifts is based on the process of non-ionic diffusion which has been discussed generally by Milne, Scribner and Crawford (19), and for this system by Robin and associates (18), and by Stabenau, Warren and Rall (20). In dogs receiving a constant infusion of ammonium acetate, a rise in arterial plasma total ammonium concentration is produced by infusion of $\mathrm{HCl}$ and a fall is produced by infusion of $\mathrm{NaHCO}_{3}$. In 2 dogs, not receiving ammonium salt infusion, the endogenous arterial plasma total ammonium level was measured during a control period, and during $\mathrm{HCl}$ and $\mathrm{NaHCO}_{3}$ infusions. The details of procedure in these 2 dogs were as follows.

Dog no. 1. After drawing a control arterial blood sample for $\mathrm{pH}, \mathrm{CO}_{2}$ content, hematocrit, and plasma total ammonium determinations, $270 \mathrm{mEq} \mathrm{NaHCO}$ was infused at $18 \mathrm{mEq}$ per minute. Toward the end of the infusion another arterial blood sample was obtained for the same determinations. Ninety $\mathrm{mEq} \mathrm{HCl}$ was then infused at $6 \mathrm{mEq}$ per minute. Toward the end of this infusion a final arterial blood sample was obtained for the same determinations.

Dog no. 2. After drawing a control arterial blood sample, $50 \mathrm{mEq} \mathrm{HCl}$ was infused at $2 \mathrm{mEq}$ per minute. Toward the end of the infusion period another arterial blood sample was obtained. Four hundred $\mathrm{mEq}$ of $\mathrm{Na}-$ $\mathrm{HCO}_{3}$ was then infused at $10 \mathrm{mEq}$ per minute. Toward the end of the infusion a final arterial blood sample was obtained.

Ventilation was not controlled in either dog so that $\mathrm{Paco}_{2}$ values varied. This must be kept in mind when evaluating the $\mathrm{pH}$ changes produced in relation to shifts in plasma total ammonium concentrations.

\section{RESULTS}

Determination of $p K_{a}^{\prime}$. In Table I are shown the data in dogs receiving ammonium acetate infusions and $16 \mathrm{pK}_{\mathrm{a}}^{\prime}$ values calculated from these data. The mean $\mathrm{pK}_{\mathrm{a}}^{\prime}$ was $9.13 \pm 0.15$ over a $\mathrm{pH}$ range of 6.75 to 7.61 . In Table II are shown similar data for ten dogs and two humans not receiving ammonium salt infusions with $12 \mathrm{pK}_{\mathrm{a}}^{\prime}$ values calculated from these data. The mean $\mathrm{pK}_{\mathrm{a}}^{\prime}$ was 9.15 \pm 0.49 over a $\mathrm{pH}$ range of 7.10 to 7.42 . Analysis by a modified $t$ test reveals no significant differ- ence between these two means. The average whole blood total ammonium concentration in the normal anesthetized dog is $81 \mu$ moles $\mathrm{NH}_{3}-\mathrm{N}$ per $\mathrm{L} \pm 28$. The average normal alveolar ammonia gas tension is $0.5 \times 10^{-4} \mathrm{~mm} \mathrm{Hg} \pm 0.6$.

Cerebrospinal fluid/arterial blood ratios of total ammonium concentration. In Table III are shown pairs of simultaneous cerebrospinal fluid and arterial whole blood total ammonium levels in dogs receiving ammonium acetate infusions. The mean ratio of cerebrospinal fluid to arterial blood total ammonium concentration at arterial $\mathrm{pH}$ values of 7.3 to 7.5 was $0.48 \pm 0.09$.

In Table IV are shown 7 simultaneous pairs of cerebrospinal fluid and whole blood total ammonium levels in uninfused dogs. In two of these studies a cerebrospinal fluid total ammonium concentration of zero was obtained. In both cases, technical difficulties rendered these results questionable. In one study, only a very small volume of cerebrospinal fluid was obtainable, necessitating a large dilution before analysis. In the other, an unusually low color development with ninhydrin was observed in the analyses done that day. For

TABLE I

$p K^{\prime}{ }_{a}$ in dogs infused with ammonium acetate

\begin{tabular}{|c|c|c|c|c|c|}
\hline Dog & $\mathrm{PANH}_{3}$ & $\begin{array}{c}\text { Calculated } \\
\text { art. } \\
\text { plasma } \\
\left(\mathrm{NH}_{3}^{\circ}\right)\end{array}$ & $\begin{array}{c}\text { Art. } \\
\text { blood } \\
\text { total } \\
\text { amm. }\end{array}$ & $\begin{array}{c}\text { Art. } \\
\text { blood } \\
\text { pH }\end{array}$ & $\mathrm{pK}^{\prime} \mathrm{a}$ \\
\hline & $\underset{\times 10^{-4}}{m m}$ & $\mu$ moles $/ L$ & $\mu m o l e s / L$ & & \\
\hline 1 & $\begin{array}{l}5.8 \\
7.9\end{array}$ & $\begin{array}{l}25.2 \\
34.3\end{array}$ & $\begin{array}{l}2,240 \\
1,590\end{array}$ & $\begin{array}{l}7.13 \\
7.52\end{array}$ & $\begin{array}{l}9.08 \\
9.18\end{array}$ \\
\hline 2 & $\begin{array}{l}1.9 \\
1.8\end{array}$ & $\begin{array}{l}8.3 \\
7.8\end{array}$ & $\begin{array}{l}578 \\
938\end{array}$ & $\begin{array}{l}7.32 \\
6.75\end{array}$ & $\begin{array}{l}9.16 \\
8.82\end{array}$ \\
\hline 3 & $\begin{array}{l}2.7 \\
0.6\end{array}$ & $\begin{array}{r}11.7 \\
2.6\end{array}$ & $\begin{array}{r}1,060 \\
379\end{array}$ & $\begin{array}{l}7.32 \\
6.95\end{array}$ & $\begin{array}{l}9.28 \\
9.12\end{array}$ \\
\hline 4 & 3.6 & 15.6 & 2,340 & 7.10 & 9.14 \\
\hline 5 & 2.0 & 8.7 & 1,075 & 7.31 & 9.41 \\
\hline 6 & $\begin{array}{r}15.1 \\
3.4\end{array}$ & $\begin{array}{l}65.6 \\
14.8\end{array}$ & $\begin{array}{l}2,145 \\
1,300\end{array}$ & $\begin{array}{l}7.32 \\
7.13\end{array}$ & $\begin{array}{l}8.83 \\
9.08\end{array}$ \\
\hline 7 & $\begin{array}{l}1.3 \\
1.6\end{array}$ & $\begin{array}{l}5.6 \\
7.0\end{array}$ & $\begin{array}{l}326 \\
251\end{array}$ & $\begin{array}{l}7.30 \\
7.51\end{array}$ & $\begin{array}{l}9.05 \\
9.07\end{array}$ \\
\hline 8 & $\begin{array}{l}0.8 \\
1.1\end{array}$ & $\begin{array}{l}3.5 \\
4.8\end{array}$ & $\begin{array}{l}264 \\
192\end{array}$ & $\begin{array}{l}7.33 \\
7.61\end{array}$ & $\begin{array}{l}9.19 \\
9.23\end{array}$ \\
\hline 9 & $\begin{array}{l}1.3 \\
1.7\end{array}$ & $\begin{array}{l}5.6 \\
7.4\end{array}$ & $\begin{array}{l}450 \\
339\end{array}$ & $\begin{array}{l}7.29 \\
7.56\end{array}$ & $\begin{array}{l}9.20 \\
9.24\end{array}$ \\
\hline & & & & \multicolumn{2}{|c|}{ Mean: $9.13 \pm 0.15$} \\
\hline
\end{tabular}


TABLE II

$p K^{\prime}$ a in ten dogs and two humans not infused with ammonium acetate

\begin{tabular}{|c|c|c|c|c|c|}
\hline Subject & $\mathrm{P}_{\mathbf{A}} \mathrm{NH}_{3}$ & $\begin{array}{c}\text { Calcu- } \\
\text { lated } \\
\text { art. } \\
\text { plasma } \\
\left(\mathrm{NH}_{3}{ }^{\circ}\right)\end{array}$ & $\begin{array}{c}\text { Arterial } \\
\text { blood } \\
\text { total } \\
\text { ammo- } \\
\text { nium }\end{array}$ & $\begin{array}{c}\text { Art. } \\
\text { blood } \\
\text { pH }\end{array}$ & $\mathrm{pK}^{\prime} \mathrm{s}$ \\
\hline no. & $\underset{\times 10^{-4}}{m m} H g$ & umoles!L & umoles $/ L$ & & \\
\hline $\begin{array}{r}\text { Dog } \\
1 \\
2 \\
3 \\
4 \\
5 \\
6 \\
7 \\
8 \\
9 \\
10\end{array}$ & $\begin{array}{l}0.20 \\
0.11 \\
0.27 \\
1.79 \\
0.50 \\
0.34 \\
1.65 \\
0.27 \\
0.09 \\
0.20\end{array}$ & $\begin{array}{l}0.86 \\
0.48 \\
1.16 \\
7.76 \\
2.19 \\
1.49 \\
7.16 \\
1.15 \\
0.40 \\
0.89\end{array}$ & $\begin{array}{r}62 \\
94 \\
61 \\
75 \\
87 \\
64 \\
109 \\
119 \\
103 \\
134\end{array}$ & $\begin{array}{l}7.25 \\
7.38 \\
7.41 \\
7.36 \\
7.31 \\
7.23 \\
7.10 \\
7.35 \\
7.31 \\
7.24\end{array}$ & $\begin{array}{l}9.11 \\
9.67 \\
9.15 \\
8.35 \\
8.91 \\
8.86 \\
8.28 \\
9.37 \\
9.66 \\
9.42\end{array}$ \\
\hline $\begin{array}{c}\text { Humans } \\
\text { M. H. } \\
\text { A. G. }\end{array}$ & $\begin{array}{l}0.39 \\
0.12\end{array}$ & $\begin{array}{l}1.69 \\
0.51\end{array}$ & $\begin{array}{r}96 \\
150\end{array}$ & $\begin{array}{l}7.42 \\
7.38\end{array}$ & $\begin{array}{l}9.18 \\
9.85\end{array}$ \\
\hline \multicolumn{6}{|c|}{ Mean : $9.15 \pm 0.49$} \\
\hline
\end{tabular}

this reason, these two values have been excluded from the calculation of the mean. The mean cerebrospinal fluid/arterial blood ratio of the remain-

TABLE III

Simultaneous cerebrospinal fluid and arterial blood total ammonium concentrations in dogs infused with ammonium acetate

\begin{tabular}{|c|c|c|c|}
\hline Dog & $\begin{array}{l}\text { Cerebro- } \\
\text { spinal } \\
\text { fluid } \\
\text { total } \\
\text { ammonium }\end{array}$ & $\begin{array}{c}\text { Arterial } \\
\text { blood } \\
\text { total } \\
\text { ammonium }\end{array}$ & $\begin{array}{c}\mathrm{CSF} / \text { arterial } \\
\text { ratio }\end{array}$ \\
\hline no. & $\mu$ moles $/ L$ & umoles $/ L$ & \\
\hline 1 & $\begin{array}{l}181 \\
156 \\
218 \\
217 \\
229 \\
243\end{array}$ & $\begin{array}{l}344 \\
331 \\
351 \\
390 \\
368 \\
424\end{array}$ & $\begin{array}{l}0.53 \\
0.47 \\
0.62 \\
0.56 \\
0.62 \\
0.57\end{array}$ \\
\hline 2 & $\begin{array}{l}251 \\
312 \\
314 \\
269 \\
279\end{array}$ & $\begin{array}{l}647 \\
566 \\
588 \\
641 \\
658\end{array}$ & $\begin{array}{l}0.39 \\
0.55 \\
0.53 \\
0.42 \\
0.42\end{array}$ \\
\hline 3 & $\begin{array}{l}271 \\
307 \\
279\end{array}$ & $\begin{array}{l}771 \\
757 \\
628\end{array}$ & $\begin{array}{l}0.35 \\
0.41 \\
0.44\end{array}$ \\
\hline 4 & 191 & 588 & 0.32 \\
\hline 5 & 321 & 728 & 0.44 \\
\hline 6 & 309 & 591 & 0.52 \\
\hline \multicolumn{4}{|c|}{ Mean: $0.48 \pm 0.09$} \\
\hline
\end{tabular}

ing five studies was $0.35 \pm 0.12$. These two means are not significantly different.

$\mathrm{NH}_{4}-\mathrm{NH}_{3}$ system as an indicator of intracellular-extracellular acid-base relations. In Table V are shown levels of arterial plasma total ammonium at control $\mathrm{pH}$ and with $\mathrm{pH}$ modified by $\mathrm{HCl}$ and $\mathrm{NaHCO}_{3}$ administration in a typical dog receiving a constant infusion of ammonium acetate. Arterial $\mathrm{pH}$ and $\mathrm{pCO}_{2}$ values are also given for each point. Similar data are given for the two dogs not receiving ammonium infusions.

The pattern of response of the arterial plasma total ammonium levels to alterations of arterial $\mathrm{pH}$ by $\mathrm{HCl}$ or $\mathrm{NaHCO}_{3}$ in both infused and uninfused animals is the same.

Filtrate stability. Table VI summarizes the data on filtrates stored at $-10^{\circ} \mathrm{C}$. Within the limits of experimental error, filtrates were stable up to three weeks under these conditions.

Plasma-erythrocyte total ammonium ratios. In Table VII are shown values for arterial plasma total ammonium, erythrocyte total ammonium, and simultaneous $\mathrm{pH}$, hematocrit, and independent whole blood total ammonium, when obtained. Whole blood total ammonium levels calculated from hematocrit and erythrocyte and plasma concentrations are in close agreement with the experimentally determined whole blood values.

The ratio of erythrocyte/plasma total ammonium (uncorrected for plasma water and for erythrocyte water) in four animals receiving ammonium acetate infusions is approximately constant (1.36 to 1.42 ).

TABLE IV

Simultaneous cerebrospinal fluid and arterial blood total ammonium concentrations in dogs not infused with ammonium acetate

\begin{tabular}{|c|c|c|c|}
\hline Dog & $\begin{array}{l}\text { Cerebro- } \\
\text { spinal } \\
\text { fluid } \\
\text { total } \\
\text { ammonium }\end{array}$ & $\begin{array}{c}\text { Arterial } \\
\text { blood } \\
\text { total } \\
\text { ammonium }\end{array}$ & $\begin{array}{c}\text { CSF/arterial } \\
\text { ratio }\end{array}$ \\
\hline no. & Mmoles/L & umoles $/ L$ & \\
\hline $\begin{array}{l}1 \\
2 \\
3 \\
4 \\
5 \\
6\end{array}$ & $\begin{array}{r}0 \\
36 \\
12 \\
22 \\
0 \\
23 \\
22\end{array}$ & $\begin{array}{r}57 \\
82 \\
46 \\
43 \\
113 \\
76 \\
100\end{array}$ & $\begin{array}{r}0^{*} \\
0.44 \\
0.26 \\
0.51 \\
0^{*} \\
0.30 \\
0.22\end{array}$ \\
\hline
\end{tabular}

Mean : $0.35 \pm 0.12$

* Excluded from mean because of technical difficulties. 
TABLE $\mathbf{V}$

Variation of arterial plasma total ammonium concentrations with $p H$

\begin{tabular}{|c|c|c|c|}
\hline Type of experiment & $\begin{array}{l}\text { Arterial } \\
\text { pH }\end{array}$ & $\mathrm{P}_{2 \mathrm{CO}_{2}}$ & $\begin{array}{c}\text { Plasma } \\
\text { total } \\
\text { ammonium }\end{array}$ \\
\hline $\begin{array}{l}\text { Dog infused with } \\
\text { ammonium acetate }\end{array}$ & & $m m H_{g}$ & umoles $/ L$ \\
\hline $\begin{array}{l}\text { 1. Control } \\
\text { 2. } \mathrm{NaHCO} \text { infused } \\
\text { 3. } \mathrm{HCl} \text { infused } \\
\text { 4. } \mathrm{HCl} \text { infused }\end{array}$ & $\begin{array}{l}7.36 \\
7.79 \\
7.65 \\
7.14\end{array}$ & $\begin{array}{l}31.0 \\
30.5 \\
30.0 \\
29.5\end{array}$ & $\begin{array}{r}772 \\
329 \\
428 \\
1,160\end{array}$ \\
\hline $\begin{array}{l}\text { Dog not infused with } \\
\text { ammonium acetate } \\
\text { 1. Control } \\
\text { 2. } \mathrm{NaHCO}_{3} \text { infused } \\
\text { 3. } \mathrm{HCl} \text { infused }\end{array}$ & $\begin{array}{l}7.27 \\
7.52 \\
7.24\end{array}$ & $\begin{array}{l}51.0 \\
72.0 \\
61.0\end{array}$ & $\begin{array}{l}94 \\
63 \\
88\end{array}$ \\
\hline $\begin{array}{l}\text { Dog not infused with } \\
\text { ammonium acetate } \\
\text { 1. Control } \\
\text { 2. } \mathrm{NaHCO} \text { infused } \\
\text { 3. } \mathrm{HCl} \text { infused }\end{array}$ & $\begin{array}{l}7.36 \\
7.59 \\
7.00\end{array}$ & $\begin{array}{l}49.0 \\
67.0 \\
40.0\end{array}$ & $\begin{array}{r}123 \\
75 \\
137\end{array}$ \\
\hline
\end{tabular}

\section{DISCUSSION}

All blood ammonia analytical methods involve alkalinization of the blood in order to volatilize ammonium ion as ammonia gas followed by trapping the liberated ammonia gas in dilute acid. The $\mathrm{NH}_{4}{ }^{+}$content of the resulting water solution is then analyzed titrimetrically or colorimetrically.

In the recent renewal of interest in ammonia metabolism, the most commonly used analytical method has been the microdiffusion technique of Conway and Cooke (2). Conway emphasized the importance of using precisely constructed and processed diffusion units. He also indicated that several correction factors were necessary, including one for incomplete diffusion. At room temperature, only about half the total ammonium in water solution was liberated in a ten minute diffusion period. Other corrections were made for
TABLE VI

Stability of trichloracetic acid filtrates of blood at $-10^{\circ} \mathrm{C}$

\begin{tabular}{|c|c|c|c|}
\hline \multicolumn{2}{|c|}{ Infused dog } & \multicolumn{2}{|c|}{ Noninfused dog } \\
\hline Day & $\begin{array}{c}\text { Total } \\
\text { ammonium }\end{array}$ & Day & $\begin{array}{c}\text { Total } \\
\text { ammonium }\end{array}$ \\
\hline & $\underset{\text { filtrate }}{\mu \text { moles } / L}$ & & $\begin{array}{c}\mu m o l e s / L \\
\text { filtrate }\end{array}$ \\
\hline $\begin{array}{r}1 \\
2 \\
3 \\
5 \\
9 \\
19 \\
57\end{array}$ & $\begin{array}{l}259 \\
256 \\
235 \\
251 \\
279 \\
274 \\
289\end{array}$ & $\begin{array}{r}1 \\
3 \\
8 \\
16 \\
24\end{array}$ & $\begin{array}{l}40 \\
53 \\
46 \\
68 \\
47\end{array}$ \\
\hline
\end{tabular}

the "deaminating" action of alkali on blood, and for the slower release of $\mathrm{NH}_{3}$ gas from bloodcarbonate mixtures as opposed to water-carbonate mixtures (21). Most investigators using the Conway method have specified neither the precise conditions under which determinations were made, nor which, if any, of the correction factors were used.

The other analytical method in general use today, introduced by Seligson and Seligson in 1951 (4), allowed for complete diffusion by mechanical rotation of the diffusion chamber. A variant of this procedure was introduced by Nathan and Rodkey (7), who prepared a protein-free filtrate of blood with ice-cold trichloracetic acid immediately after shedding. This method had the theoretical advantage of reducing the magnitude of enzymatically catalyzed reactions which produced artifactual concentrations of total ammonium after shedding, and the additional advantage that the ammonium content of ice-cold trichloracetic acid filtrates was stable for at least one hour, permitting duplicate or triplicate analyses. Our data (Table VI) indicate that trichloracetic acid filtrates are stable at $-10^{\circ} \mathrm{C}$ for several weeks, which further

TABLE VII

Erythrocyte and plasma total ammonium concentrations

\begin{tabular}{|c|c|c|c|c|c|c|c|}
\hline \multirow[b]{2}{*}{ Dog } & \multirow[b]{2}{*}{$\begin{array}{c}\text { Arterial } \\
\text { pH }\end{array}$} & \multirow[b]{2}{*}{ Hematocrit } & \multicolumn{4}{|c|}{ Total ammonium } & \multirow[b]{2}{*}{$\begin{array}{c}\text { Eryth./plasma } \\
\text { ratio }\end{array}$} \\
\hline & & & Plasma & $\begin{array}{l}\text { Erythro- } \\
\text { cyte }\end{array}$ & $\begin{array}{l}\text { Whole } \\
\text { blood }\end{array}$ & $\begin{array}{l}\text { Calc. } \\
\text { whole } \\
\text { blood }\end{array}$ & \\
\hline & & & umoles/L & umoles $/ L$ & $\mu$ moles $/ L$ & $\mu m o l e s / L$ & \\
\hline $\begin{array}{l}1 \\
2 \\
3 \\
4\end{array}$ & $\begin{array}{l}7.38 \\
7.50 \\
7.36\end{array}$ & $\begin{array}{l}0.38 \\
0.47 \\
0.45\end{array}$ & $\begin{array}{l}512 \\
557 \\
379 \\
371\end{array}$ & $\begin{array}{l}698 \\
529 \\
529\end{array}$ & $\begin{array}{l}547 \\
596 \\
438 \\
466\end{array}$ & $\begin{array}{l}583 \\
449 \\
435\end{array}$ & $\begin{array}{l}1.36 \\
1.36 \\
1.40 \\
1.42\end{array}$ \\
\hline
\end{tabular}


extends the usefulness of the procedure of Nathan and Rodkey.

A major difficulty of such methods resides in the fact that blood gives rise to increasing amounts of alkali-volatile material on standing. This fact was evidently not fully appreciated by early workers, and it was not until the investigations of Folin and Denis (22), Barnett (23) and Nash and Benedict (24) that values of about $70 \mu$ moles $\mathrm{NH}_{3}-\mathrm{N}$ per $\mathrm{L}$ blood were obtained. Using rapid vacuum steam-distillation of blood alkalinized with borate buffer, Klisiecki and Parnas found the peripheral venous blood $\mathrm{NH}_{3}-\mathrm{N}$ concentration in nonfasted resting mammals (including man) was less than $35 \mu$ moles per $\mathrm{L}(25,26)$.

Normal peripheral venous blood $\mathrm{NH}_{3}-\mathrm{N}$ levels as measured by Seligson diffusion methods vary from 50 to $100 \mu$ moles per $L(5,27,28)$. Values up to $70 \mu$ moles per $\mathrm{L}$ usually are accepted as normal using the Conway method (21), but levels as high as $200 \mu$ moles per $\mathrm{L}$ have been reported as normal (30).

One of the difficulties of interpreting results obtained with the Conway method is that Conway described a rapid increase in blood total ammonium concentration which began immediately after shedding and reached a relative plateau within two to three minutes. By extrapolation of the data back to the time of shedding it was thought that the normal in vivo peripheral venous blood total ammonium level was actually zero. Conway and Cooke labeled this initial increase as the "alpha"-ammonia and believed it was largely due to the decomposition of adenine derivatives (31). This work was repeated and confirmed in humans by White, Phear, Summerskill and Sherlock (29). These workers therefore accepted the "alpha"-ammonia as the "normal" level. Although the source(s) of the "alpha"-ammonia and its possible variations under different conditions were very poorly defined, it seems to have been tacitly assumed that the "alpha"-ammonia could be regarded as a constant value under all experimental circumstances. Conway himself says, "It is reasonable to assume that a significant elevation of the blood ammonia over the normal 'alpha' level is due to so much free ammonia in the circulating blood. .." (21). Although it is true that ammonium added to blood is close to 100 per cent recoverable, it is of note that no experiments have been reported (to the authors' knowledge) in which bloods with an "elevated" in vivo total ammonium level have been subjected to multiple rapid serial analyses with extrapolation back to zero time of shedding.

Conflicting results have been reported by Nelson and Seligson (5). Using the method of Seligson and Hirahara (6), they found significant levels of total ammonium in peripheral venous blood and claimed that they were measuring "true" blood ammonia independent of chemical artifact.

The potential sources of arterial ammonia may be briefly discussed. Portal venous blood contains high ammonia levels, especially in the flow from the large intestine, presumably as a result of bacterial action on nitrogenous intestinal materials $(1,22,26,29,32)$. Although this blood is largely deammoniated in its passage through the normal liver and converted into urea, some ammonia may escape to the hepatic vein particularly in the presence of relative insufficiency of the ureaforming mechanism (33). Any portal blood which circumvents the liver to flow directly into the vena cava will also contribute ammonia to arterial blood. Normal renal venous blood consistently shows high ammonia levels, presumably from the deamidation of glutamine and the deamination of amino acids $(24,26,29)$. Exercising muscle releases $\mathrm{NH}_{3}$ into the venous return (34, $35)$. Brain and other peripheral tissues may release ammonia under certain conditions (36). The possible role of the widely distributed amine oxidases acting on circulating amines has been mentioned (37). Finally, of course, the same substrates which are postulated to give rise to ammonia by decomposition in shed blood may be continually producing small amounts of ammonia in vivo. From all these sources, therefore, ammonia may enter the venous return to the heart, thence through the lungs, to appear in the arterial blood. The major organ to remove ammonia from blood is probably the liver, although positive arteriovenous ammonium differences have been demonstrated under certain conditions for brain and for limb tissues $(27,36)$. Our data indicate that ammonia is also excreted by the lung. The loss by this route is quite small, averaging approximately $1 \mathrm{mg}$ of $\mathrm{NH}_{3}$ per day.

The results of the present investigations are consistent with the hypothesis that arterial blood of anesthetized dogs does contain significant quan- 
tities of circulating ammonia. The correspondence of the $\mathrm{pK}_{\mathrm{a}}^{\prime}$ values calculated for animals infused with ammonium acetate $(9.13 \pm 0.15)$ and for uninfused animals $(9.15 \pm 0.49)$, the correspondence of the ratio of cerebrospinal fluid/arterial ammonium concentrations in both groups of animals $(0.48 \pm 0.01$ versus $0.35 \pm 0.12)$, and the similarity in response of the $\mathrm{NH}_{4}{ }^{+}-\mathrm{NH}_{3}$ system to $\mathrm{HCl}$ and $\mathrm{NaHCO}_{3}$ infusions in both groups of animals, constitute evidence that the arterial blood of dogs contains measurable amounts of total ammonium in vivo. The magnitude of the standard deviations from the mean, particularly in the uninfused animals, may be accounted for by the several sources of error discussed for the determination of $\mathrm{pK}_{\mathrm{a}}^{\prime}$ in Methods. Data in the literature are in general agreement with these results. Jacquez, Poppell and Jeltsch (38) measured $\mathrm{PA}_{\mathrm{NH}_{3}}$, arterial plasma total ammonium concentrations and arterial $\mathrm{pH}$ in dogs with portacaval shunts. Good agreement was found between measured values of $\mathrm{PA}_{\mathrm{NH}_{3}}$ and values of $\mathrm{Pa}_{\mathrm{NH}_{3}}$ calculated from arterial plasma total ammonium concentrations, $\mathrm{pH}$ and $\mathrm{pK}_{\mathrm{a}}^{\prime}$. The value of $\mathrm{pK}_{\mathrm{a}}^{\prime}$ employed was calculated by Jacquez and associates (17) from data in the chemical literature for water solutions and given as 9.02 at $37^{\circ} .^{2}$ After having also investigated two normal dogs, they concluded that "the check between the alveolar $\mathrm{P}_{\mathrm{NH}_{3}}$ and the calculated plasma $\mathrm{P}_{\mathrm{NH}_{3}}$ is independent corroborative evidence that the total plasma ammonia measured by our method is of the correct order of magnitude and corresponds to the amount present in plasma in vivo."

The spinal fluid data of Stabenau and associates $(20)$ in anesthetized dogs receiving ammonium salts intravenously showed a ratio of 0.49 between cerebrospinal fluid and arterial blood total ammonium concentrations. This compares with our value of 0.48 . In seven normal humans,

2 It is of interest that this $\mathrm{pK}^{\prime} \mathrm{a}$ is considerably lower than what has been frequently assumed on the basis of the dissociation constant of $\mathrm{NH}_{4} \mathrm{OH}$ in water solution $\left(1.8 \times 10^{-5}\right.$ at $\left.25^{\circ}\right) ; \mathrm{pK}_{\mathrm{a}}^{\prime}=9.4$. Bank and Schwartz measured the ammonium $\mathrm{pK}_{\mathrm{a}}^{\prime}$ of solutions containing a variety of solutes normally found in urine in high concentrations. They obtained a value of approximately 9.03 in solutions with the ionic strength of plasma at $37^{\circ} \mathrm{C}$ (39). Our value of 9.13 is probably high since whole blood total ammonium concentrations were measured rather than plasma concentrations.
Clarke and colleagues, quoted in a paper by Summerskill, Wolfe and Davidson (40), found an average arterial total $\mathrm{NH}_{3}-\mathrm{N}$ level of $37 \mu$ moles per $\mathrm{L}$ while simultaneous cerebrospinal fluid levels were $14 \mu$ moles per L, giving a ratio of 0.38 which compares to our ratio of 0.35 in dogs. In four patients with "hepatic" coma, they found ammonium ratios of cerebrospinal fluid/arterial blood varying from 0.4 to 2.4 . In three patients with severe liver disease, we found ratios of $0.54,0.72$ and 0.76 . The similarity of the cerebrospinal fluid/arterial blood total ammonium concentration ratios both in ammonium-infused and noninfused preparations suggests that cerebrospinal fluid and arterial blood do contain significant ammonium levels in vivo in the uninfused animal. Most of the potential sources of ammonia formation in blood after shedding are found only intracellularly (41) and would not be expected to be present in an acellular fluid like cerebrospinal fluid. However, it must be noted that glutamine, an obvious potential source of ammonia, is present both in plasma and in cerebrospinal fluid (42).

It has been shown that in dogs receiving a constant infusion of ammonium acetate, relative extracellular acidosis produces a rise, and relative extracellular alkalosis produces a fall, in arterial plasma total ammonium concentrations (18). As long ago as 1926, Parnas and Klisiecki showed that the infusion of acid salts produced a marked rise in blood ammonia levels of normal dogs (26). Comparable results using acid and alkali infusions were also obtained by Lawrence and associates (43) in normal and in Eck-fistula dogs. Thus, the physicochemical behavior of the alkali-labile material in the blood is similar both in ammoniuminfused and in noninfused dogs. Since the nature of this material is known in the infused animals, it seems reasonable to conclude that the arterial blood of dogs contains approximately 81 $\mu$ moles $\mathrm{NH}_{3}-\mathrm{N}$ per $\mathrm{L}$, and that normally $\mathrm{PA}_{\mathrm{NH}_{3}}$ averages $0.5 \times 10^{-4} \mathrm{~mm} \mathrm{Hg}$.

Since the physicochemical relations discussed involve plasma and extracellular fluid rather than whole blood, it seemed of interest to define the respective contributions of the red cell and plasma to the whole blood total ammonium. Previous investigators $(6,9,44)$ have noted that erythrocytes generally contain more ammonia per unit volume than plasma. Seligson and Hirahara (6) 
showed that this ratio could not be attributed to preferential erythrocyte generation of ammonia after shedding.

Our measurements were made on dogs receiving ammonium acetate infusions, and small errors due to ammonia liberation after shedding were minimized by the high pre-existing levels. At normal blood pH's the ratio of erythrocyte to plasma total ammonium concentration, expressed per volume of material analyzed, averaged 1.4. It seems probable that this ratio reflects the hydrogen ion gradient across the red cell membrane, ammonia penetrating the red cell by non-ionic diffusion as $\mathrm{NH}_{3}$ gas (45), so that,

$$
\frac{\left[\mathrm{NH}_{4}{ }^{+}\right] \text {red cell }}{\left[\mathrm{NH}_{4}{ }^{+}\right] \text {plasma }}=\frac{\left[\mathrm{H}^{+}\right] \text {red cell }}{\left[\mathrm{H}^{+}\right] \text {plasma }} \text {. }
$$

Since the intracellular erythrocyte $\mathrm{pH}$ is known to be more acid than plasma $\mathrm{pH}$ (46), a ratio greater than 1.0 would be expected.

\section{SUM MARY}

1. The arterial blood total ammonium concentration of the anesthetized dog averages $81 \mu$ moles $\mathrm{NH}_{3}-\mathrm{N}$ per $\mathrm{L} \pm 28$ as measured by the method of Nathan and Rodkey (7).

2. This level appears to represent in vivo circulating ammonia since the physicochemical behavior of the $\mathrm{NH}_{4}{ }^{+}-\mathrm{NH}_{3}$ system is similar in dogs infused with ammonium acetate and in uninfused dogs.

3. The $\mathrm{pK}_{\mathrm{a}}^{\prime}$ of $\mathrm{NH}_{4}{ }^{+} \rightleftharpoons \mathrm{NH}_{3}{ }^{\circ}+\mathrm{H}^{+}$is $9.13 \pm$ 0.15 and $9.15 \pm 0.49$ in the infused and uninfused dogs, respectively. The cerebrospinal fluid/arterial blood total ammonium concentration ratio is $0.48 \pm 0.09$ and $0.35 \pm 0.12$ in the infused and uninfused dogs, respectively. The tension of $\mathrm{NH}_{3}$ in the alveolar air of uninfused dogs averages $0.49 \pm 0.6 \times 10^{-4} \mathrm{~mm} \mathrm{Hg}$.

4. An anaerobic technique for separating erythrocytes and plasma for ammonium analysis is described.

5. Trichloracetic acid filtrates are stable with respect to their ammonia content when stored at $-10^{\circ} \mathrm{C}$ for up to three weeks.

6. The relationship between erythrocyte and plasma total ammonium concentrations is discussed. At normal blood $\mathrm{pH}(7.30$ to 7.50$)$ the erythrocyte/plasma ratio is 1.4 .

\section{REFERENCES}

1. Kirk, E. Amino acid and ammonia metabolism in liver diseases. Acta med. scand. 1936, 89, suppl. 77.

2. Conway, E. J., and Cooke, R. Blood ammonia. Biochem. J. 1939, 33, 457.

3. Koprowski, H., and Uninski, H. Ammonia content of canine blood after oral administration of ammonium salts and ammonia. Biochem. J. 1939, 33, 747.

4. Seligson, D., and Seligson, H. A microdiffusion method for the determination of nitrogen liberated as ammonia. J. Lab. clin. Med. 1951, 38, 324.

5. Nelson, R. M., and Seligson, D. Studies on blood ammonia in normal and shock states. Surgery 1953, 34, 1.

6. Seligson, D., and Hirahara, K. The measurement of ammonia in whole blood, erythrocytes, and plasma. J. Lab. clin. Med. 1957, 49, 962.

7. Nathan, D. G., and Rodkey, F. L. A colorimetric procedure for the determination of blood ammonia. J. Lab. clin. Med. 1957, 49, 779.

8. Robin, E. D., Travis, D. M., Bromberg, P. A., Forkner, C. E., Jr., and Tyler, J. M. Ammonia excretion by mammalian lung. Science 1959, 129, 270.

9. Parnas, J. K., and Heller, J. Ueber den Ammoniakgehalt und über die Ammoniakbildung im Blute (I). Biochem. Z. 1924, 152, 1.

10. Strehler, E., Haas, J., and Rupp, F. Der Einfluss von $\mathrm{CO}_{2}$ auf den Ammoniak-gehalt des Blutes in vitro. Biochem. Z. 1942, 313, 170.

11. Rosenthal, T. B. The effect of temperature on $\mathrm{pH}$ of blood and plasma in vitro. J. biol. Chem. 1948, 173, 25.

12. Van Slyke, D. D., and Neill, J. M. The determination of gases in blood and other solutions by vacuum extraction and manometric measurement, I. J. biol. Chem. 1924, 61, 523.

13. Van Slyke, D. D., and Sendroy, J., Jr. Studies of gas and electrolyte equilibria in blood. XV. J. biol. Chem. 1928, 79, 781.

14. Cullen, G. E., Keeler, H. R., and Robinson, H. W. The $\mathrm{pK}^{\prime}$ of the Henderson-Hasselbalch equation for hydrion concentration of serum. J. biol. Chem. 1925, 66, 301.

15. Peters, J. P., and Van Slyke, D. D. Quantitative Clinical Chemistry. Methods. Baltimore, Williams and Wilkins, 1932, vol. II, p. 292.

16. Bohr, C. Ueber die Lungenathmung. Skand. Arch. Physiol. 1890, 2, 236.

17. Jacquez, J. A., Poppell, J. W., and Jeltsch, R. Solubility of ammonia in human plasma. J. appl. Physiol. 1959, 14, 255.

18. Robin, E. D., Bromberg, P. A., and Forkner, C. E., Jr. Unpublished data.

19. Milne, M. D., Scribner, B. H., and Crawford, M. A. Non-ionic diffusion and the excretion of weak acids and bases. Amer. J. Med. 1958, 24, 709.

20. Stabenau, J. R., Warren, K. S., and Rall, D. P. The role of $\mathrm{pH}$ gradient in the distribution of ammonia 
between blood and cerebrospinal fluid, brain and muscle. J. clin. Invest. 1959, 38, 373.

21. Conway, E. J. Microdiffusion Analysis and Volumetric Error, 4th ed. New York, The Macmillan Co., 1958 , p. 114.

22. Folin, O., and Denis, W. Protein metabolism from the standpoint of blood and tissue analysis. II. The origin and significance of the ammonia in the portal blood. J. biol. Chem. 1912, 11, 161.

23. Barnett, G. D. The micro-titration of ammonia with some observations on normal human blood. J. biol. Chem. 1917, 29, 459.

24. Nash, T. P., Jr., and Benedict, S. R. The ammonia content of the blood and its bearing on the mechanism of acid neutralization in the animal organism. J. biol. Chem. 1921, 48, 463.

25. Klisiecki, A. Ueber Ammoniakgehalt und Ammoniakbildung im Blute (V). Biochem. Z. 1926, 172, 442.

26. Parnas, J. K., and Klisiecki, A. Ueber den Ammoniakgehalt und die Ammoniakbildung im Blute (VI). Biochem. Z. 1926, 173, 224.

27. Bessman, S. P., and Bessman, A. N. The cerebral and peripheral uptake of ammonia in liver disease with an hypothesis for the mechanism of hepatic coma. J. clin. Invest. 1955, 34, 622.

28. Fahey, J. L. Toxicity and blood ammonia rise resulting from intravenous amino acid administration in man: The protective effect of $\mathrm{L}$-arginine. J. clin. Invest. $1957,36,1647$.

29. White, L. P., Phear, E. A., Summerskill, W. H. J., and Sherlock, S. Ammonium tolerance in liver disease: Observations based on catheterization of the hepatic veins. J. clin. Invest. 1955, 34, 158.

30. Schwartz, R., Phillips, G. B., Gabuzda, G. J., Jr., and Davidson, C. S. Blood ammonia and electrolytes in hepatic coma. J. Lab. clin. Med. 1953, 42, 499.

31. Conway, E. J., and Cooke, R. The deaminase of adenosine and adenylic acid in blood and tissues. Biochem. J. 1939, 33, 479.

32. Lewis, D., Hill, K. J., and Annison, E. F. Studies on the portal blood of sheep. I. Absorption of ammonia from the rumen of the sheep. Biochem. J. 1957, 66, 587.

33. Nathans, D., Fahey, J. L., and Ship, A. G. Sites of origin and removal of blood ammonia formed dur- ing glycine infusion: Effect of L-arginine. J. Lab. clin. Med. 1958, 51, 124.

34. Parnas, J. K., Mozolowski, W., and Lewinski, W. Ueber den Ammoniakgehalt und die Ammoniakbildung im Blute (IX). Biochem. Z. 1927, 188, 15.

35. Schwartz, A. E., Lawrence, W., Jr., and Roberts, K. E. Elevation of peripheral blood ammonia following muscular exercise. J. clin. Invest. 1957, 36, 927.

36. Webster, L. T., Jr., and Gabuzda, G. J. Ammonium uptake by the extremities and brain in hepatic coma. J. clin. Invest. 1958, 37, 414.

37. Dawson, A. M., and Sherlock, S. Effect of an amineoxidase inhibitor on arterial ammonium levels in liver disease. (Preliminary communication.) Lancet, 1957, 1, 1332.

38. Jacquez, J. A., Poppell, J. W., and Jeltsch, R. Partial pressure of ammonia in alveolar air. Science 1959, 129, 269.

39. Bank, N., and Schwartz, W. B. Influence of certain urinary solutes on ammonium $\mathrm{pK}^{\prime}$ a at $37^{\circ} \mathrm{C}$. $\mathrm{J}$. appl. Physiol. In press.

40. Summerskill, W. H. J., Wolfe, S. J., and Davidson, C. S. The metabolism of ammonia and $\alpha$-keto-acids in liver disease and hepatic coma. J. clin. Invest. 1957, 36, 361.

41. Bishop, C., Rankine, D. M., and Talbott, J. H. The nucleotides in normal human blood. J. biol. Chem. 1959, 234, 1233.

42. Meister, A. Metabolism of glutamine. Physiol. Rev. 1956, 36, 103.

43. Lawrence, W., Jr., Jacquez, J. A., Dienst, S. G., Poppell, J. W., Randall, H. T., and Roberts, K. E. The effect of changes in blood $\mathrm{pH}$ on the plasma total ammonia level.' Surgery 1957, 42, 50.

44. Henriques, V., and Christiansen, E. Untersuchungen über den Ammoniakgehalt des Blutes II. Biochem. Z. 1917, 80, 297.

45. Jacobs, M. H. Some aspects of cell permeability to weak electrolytes. Cold Spr. Harb. Symp. quant. Biol. 1940, 8, 30.

46. Caldwell, P. C. Intracellular pH. Int. Rev. Cytol. 1956, 5, 229. 